\title{
Professional Guidance and Counselling Services for Open and Distance Learning Students in Nigeria
}

Ahimie $B^{a}$, Ikuburuju-Orola $A^{a}$ and Oizimende $P^{b}$

aDepartment of Educational Foundations, Faculty of Education, University of Lagos; ${ }^{b}$ Post

Primary Education Board, Benin-City

ISSN: 2788-6298

DOI: https://doi.org/10.35293/tetfle.v2i1.91

\begin{abstract}
Counselling services are common features in conventional school settings and are designed to help students resolve personal and academic issues, explore career options and attend to their social needs. It is of great concern that these services are absent in Open and Distance Learning (ODL) programmes, although the peculiar nature of the programmes reveals the urgent need for them. ODL students should be able to access guidance and counselling services just as their counterparts in the conventional school setting. The main focus of this article is to point out the relevance of professional guidance and counselling services in ODL programmes in Nigeria. An in-depth description of these services and the benefits ODL students can derive from accessing them is presented. In addition, the authors adapted a conceptual model to accentuate the expected output of professional counselling services. The purpose of this model is to present a clear explanation of the fact that adequate provision of professional counselling services will lead to the improved school, workplace and family environment. It is expected that this will lead to good behaviour and improved academic performance, invariably creating a safe school, out of school and workplace environment for ODL students. Recommendations include the creation of awareness programmes through online seminars and workshops to educate ODL students on various ways to access guidance and counselling services.
\end{abstract}

Keywords: Professional counsellors, Guidance and Counselling services, Conventional school setting, Open and Distance Learning (ODL). 


\section{Introduction}

Uncertainties, complexities and natural disasters in recent years have exposed people to various challenges. Reaction to these challenges varies depending on an individual's family background and experience. This has revealed the importance of counselling at every stage of human growth and development. All professions hinge their practice on certain principles, and counselling as a profession is not excluded. Counselling upholds the belief that "counselling is for all". This implies that everyone needs counselling at different points in their lives, therefore the service is open to all who desire to access or appropriate it. The National Policy on Education (NPE) (2014; p. 26) recommended that counselling centres should be instituted in Nigerian universities to provide counselling services to all students and staff members regardless of their mode of study and areas of expertise to foster productivity in the university environment.

Open and Distance Learning (ODL) is a mode of learning that is flexible and open to all qualified and willing students wherever they may reside. Students of this programme can access highquality lectures and lecture materials provided by experts through all forms of technologies. One of the main reasons for the advent of distance education is to provide equal access to education for citizens of the society who are not among the elite and thus do not have the opportunity and resources to receive on-campus education in an educational institution (Saykili, 2018). ODL gives the opportunity for students/learners to study at any time and in any location. According to Traxler (2018), there seems to be a clear distinction between campus education and distance learning, because one happens on campus or within campus universities and the other does not. However, many universities now exploit digital technologies to reach larger distant markets, and reach out to students who may study entirely remotely and entirely online to enable universities to have significant proportions of distance learning students.

In Nigeria, the University College Ibadan in 1947 commenced extra mural studies under the aegis of the Oxford University in the United Kingdom. This helped a good number of Nigerians who were unable to gain admission into the university but were thirsty for higher education to acquire higher education through correspondence study. Some Nigerians also registered for the Ordinary and Advanced Level General Certificate of Education (GCE) at the London and Cambridge University. Other attempts at Open and Distance Learning in Nigeria include; The Ahmadu Bello University Air Programme in 1972; The University of Lagos Distance Learning Programme in 1974; the Kaduna National Teachers' Institute (NTI) in 1978 and the National Open University (NOU) in 1984. The NOU was closed for 18 years as a result of political disturbance and was reestablished formally as the National Open University of Nigeria (NOUN) in 2002. It catered for the university education needs of thousands of students who were qualified for the higher education programme but were denied access to the existing conventional universities (Jegede, 2016).

CONTACT: Ahimie, B. bahimie@yahoo.com

This work is licensed under a Creative Commons Attribution 4.0 International License. 
Globally, there has been a growing enrolment in open and distance education as part of educational growth at all levels of education. Alongside this are the ascendance of online education, the mainstreaming of distance education, the digital transformation of education and growing competition in Open and Distance Learning (Qayyum \& Zawacki-Richter, 2019; p. 125). All these are in addition to the enormous problems associated with instructional delivery at a distance. Research and empirical studies have confirmed that individualized learning is a lonely activity; especially since most students in the distance learning programmes are faced with challenges of family, work and other social demands. These demands sometimes take precedence over their programme of study. Other problems include the lack of digital readiness among staff and ODL institutions, absence of electronic library for easy accessibility to journals from scientific database, inefficient cybercafé and internet facility within university settings (Apuke \& lyendo, 2018). There is also the problem of inconsistency in programme and policy implementation in addition to the poor power supply, poor telecommunication facilities and poor postal system.

While students in conventional institutions have access to counselling services, it appears that their ODL counterparts are unaware of these services and the benefits they can derive from them. This could be attributed to the peculiar nature of the distance learning programme where physical contact between lecturers and students is not common or regular and as such is not an environment which allows ODL students the physical opportunity to access counselling services. ODL students can take advantage of the following counselling-services provided in the university environment; orientation, appraisal, information, counselling, planning, research, placement, follow-up and follow-along, referral, consultancy, evaluation, testing, motivational service, cumulative record-keeping, in-service training programme, remedial laboratory programme, career library, career week/day programme and excursion services. These services are geared towards helping students in areas of educational/academic achievement; vocational /career development and personal/social development.

Classroom teachers/lecturers may not be equipped to handle these aspects of the lives of their students since such services can only be rendered by experts. ODL programmes may also not prepare students to offer counselling services, especially if they are not being trained as professional counsellors. However exposing ODL students to professional counselling services and the benefits derived from it, might equip them to make appropriate referrals in any setting they find themselves. The aim of this article is to present a clear description of these services and how ODL students can benefit from them. 


\section{Guidance and counselling services in the school system}

Guidance and counselling services in the school system are services rendered by professional counsellors to students regardless of their mode of study to help in their academic, career, social, emotional and personal development. When appropriately rendered, these services help students learn more about themselves, discover their potentials and be motivated to tackle and discover solutions to the problems they face daily. Ahimie, Ikuburuju-Orola and Lawal (2018) outlined the counselling services that cannot be ignored in the school system. The benefits of these services as outlined by various authors are also discussed. These services include, but are not limited to the following;

Orientation service: This is one of the most important guidance services rendered to new students in a school setting. It usually takes place as soon as new students arrive in school to start the school year. It helps them know the facilities and resources that are available in the school environment and how to locate them. For example, classrooms for lectures, departmental offices, libraries, bookshops, laboratories and health facilities are some of the facilities that students should be able to locate and use easily. Orientation service is crucial in the field of counselling because it reveals to new students, the nature of life in institutions of higher learning. Information given to new students during orientation helps them to adjust quickly to life within the institution (Agi, 2016). Orientation is a mandatory part of a new student's enrollment into college. It is a rite of passage required for the new student to enter the hallowed halls of academia. It helps new students make friends before the start of lectures; find their way around campus and learn about campus resources (Carlevatti, 2018). The Scholars Hub Africa (2019) outlined benefits of orientation to new students in a university campus, these include; the provision of a wealth of information to new students, provision of great academic advice, taking them on campus tours and providing an opportunity for them to ask questions during the question and answer sessions. They are also exposed to services and resources on campus and campus rules and regulations.

Appraisal service: This involves collecting, organizing, synthesizing, administering and interpreting data about students. The appraisal process involves; setting academic performance standards; assessing students' actual performance relative to these standards and providing feedback to students with the aim of motivating them to eliminate performance deficiencies or to continue to perform above par (Danku, Soglo, Dordor \& Bokor, 2015). HYATTRACTIONS (2015) outlined the six main principles of appraisal techniques as a testing process, administering, scoring, interpreting, communicating results to students while observing the ethical principle of confidentiality. Test results provide descriptive and objective data which help the counsellor to assist students better in making choices that will positively affect their lives. The student is then able to make a reasonable choice from different alternatives at his or her disposal (Namale \& Awabil, 2018). 
Information service: Students specifically need information about themselves, their education, the world of work and their social environment. This is because the students "cannot make effective and sound decisions on any issue without adequate and usable information. Information about issues helps them to make wise choices or sound decisions out of the alternatives open to them in any given situation" (Onyemenam, 2018, Para. 2.3.2). The researcher further stated that information services expose students to further educational opportunities and the prerequisites for them; trends in the world of work and personal and social issues in their environment. This gives the students an understanding of their interests, abilities and financial resources before making a choice. Information gives students a broad knowledge about issues and protects them from making mistakes (Sheikh, 2016).

Counselling service: This service according to Namale and Awabil (2018) is primarily designed to empower individuals to solve their problems. It is provided by trained professionals. The rationale for guidance and counselling in schools is based on the belief that prevention is always better than cure in every aspect of life. Counselling is a collaborative relationship between therapists and clients who seek to enhance their emotional or psychological well-being and therapists who provide supportive environments where clients can work towards enhancing their emotional or psychological wellbeing (Short \& Thomas, 2015, p.10). Counselling is a professional interaction between an expert and one or more individuals seeking assistance in dealing with difficulties and in making changes in their lives (Berven, Thomas \& Chan, 2015, p.1).

Planning service: This involves assisting students to plan effectively for their future and work towards the realization of such plan. Effective planning helps students make the right career choices. This is one of the major decisions students need to make in the course of their studies. The right decision will assist them in their professional lives (Zafar, 2019). There is need for adequate planning in a world where new ways of thinking are coming up in the midst of interwoven economic, environmental and social development (McGrath, Ramsarup, Zeelen, Wedekind, Allais \& Lotz-Sisitka, 2019). A well planned and organized guidance and counselling programme is essential in assisting students to cope with the stresses they face while in and out of school (Ruttoh, 2015).

Research service: Counsellors are researchers. They carry out scientific investigations on crucial issues pertaining to human behaviour such as; emotional development, behaviour modification, adolescence, academic performance, interpersonal relationship, career or vocational development and many more. Findings gained from researches conducted by counsellors are applied in addressing the myriads of issues presented by clients. Research evidence around the process and counselling outcome according to McLeod and McLeod (2015) represents a valuable resource that has the potential to enhance the quality of counselling conversations enacted by 
practitioners in health, education, social work and other professions. It is important to properly guide students who are often required to conduct diverse research work as they progress through their final years in institutions of higher learning (Apuke \& lyendo, 2018).

Placement service: This has to do with placing students in the right schools and streaming them into the right classes. It enables students to be admitted into schools of their choice to avoid frustration and job dissatisfaction in future (Namale \& Awabil, 2018). Appropriate placement into right schools and classes help students build the kind of relationships and learning opportunities they need to promote their well-being and healthy development; and this can then be transferred to the world of work (Darling-Hammond, Flook, Cook-Hurvey, Barron \& Osher, 2019).

Follow-up and Follow-along service: This is done to obtain relevant progress report on students' performances during and after therapy. It is concerned with what happens to students while in school or after they have left school. This service is designed to assess the extent the guidance programme is meeting the needs for which it was established. It is concerned essentially with successes, failures, problems and feedback from students who have benefited from the programmes. The ultimate goal of follow-up and follow-along service is to evaluate and improve on the programme or make necessary adjustments that have been indicated by the beneficiaries of the programme (Suleiman, Olanrewaju \& Suleiman, 2019).

Referral service: Professional counsellors refer students to appropriate professionals when a problem is beyond their scope or area of competence. A referral is made for specialized assistance. This happens when the problem is beyond the scope of the services provided by a counsellor (Suleiman et al., 2019). A referral is considered in counselling when the counsellor believes that a student's problem is beyond his experience and expertise or when he is not comfortable with rendering assistance with regards to the particular problem the student is experiencing (University of Central Florida, 2020). Counselling and counsellors have limitations. This should be made clear to the client as soon as the counselling session starts (Onyemenam, 2018). A client with advanced neurosis should be referred to the psychiatrist and another with a high temperature to the medical personnel. A referral can also be made when counselling issues require the assistance of experts in that area of counselling.

Consultancy service: Consultancy service is one of the indirect services rendered by counsellors in collaboration with parents, other school staff and outside agencies on behalf of the students (Pannoni \& Moody, 2020). It is a service rendered by a counsellor who serves as a consultant to the third party (client /student) by equipping him with knowledge and skills so the student's needs will be adequately met. The counsellor as a provider and manager of human resources is expected to successfully act as a consultant to personalities within and outside the school setting (Namale \& Awabil, 2018). 
Evaluation service: This service determines the extent to which all other services have been successfully implemented in the school system. Once the guidance and counselling services have been offered, there is a need for the service to be evaluated (Namale \& Awabil, 2018). It is important to evaluate the effectiveness and efficient delivery of guidance and counselling services in the school system. It is of great benefit not only to the school but also to the community as it provides information on how to manage adolescent moral development, career options, reproductive health and study skills (Samanyanga \& Ncube, 2015).

Testing service: Counsellors need to understand and assist students to make effective choices in life and acquire new behaviour. This can only be done based on information acquired from the students in some systematic and objective ways using carefully-developed testing and assessment procedures (Popoola \& Oluwatosin, 2018). The counsellor using this service in the school system collects information from students, analyzes and evaluates the student to identify his/her problems. The counsellor is then able to adequately diagnose the problem of the student to plan the treatment procedure or necessary intervention. This reveals other areas that the counsellor needs to focus on and if there has been any change in the student. Counselling psychologists subject clients to various tests in an attempt to measure their intellectual abilities. These tests include paper and pencil tests, objective tests, performance tests and subjective tests such as essay tests (Makinde \& Akanni, 2015).

Motivational service: This involves encouraging students/clients to seek counselling intervention for their problems voluntarily. Motivation involves students having either personal or group interaction with a counsellor using the motivation interview. This type of interview is a collaborative conversation style to strengthen students' motivation and commitment to change (Manthey, Brooks, Chan, Hedenblad \& Ditchman, 2015, p. 250). Motivation is a psychological force that compels or reinforces an action towards a desired goal (Adeusi, Adekeye \& Babalola, 2016). Motivation service is used to encourage students going through difficult times to seek counselling intervention voluntarily.

Cumulative record keeping: Cumulative records are objective and up-to-date information about a student from his first day in school to when he leaves and even extends to the period after graduation. Additional information about the student is accumulated over a long period. Students' cumulative records or files have general information that typically contains the students' grades, attendance, discipline, standardized assessment reports and other information from their educational career. Cumulative records also contain a history of the programmes students have attended, previous support services provided to them and their families and their educational performance history (Logsdon \& Blackburn, 2020). Heads of institutions also make use of cumulative and academic records of students to gather all information required about the 
students. Amanchukwu and Ololube (2015) advocated for the need to keep a record of all school activities such as personal details of pupils along with those of their academic performance, assessments, examinations, and all existing and accessible records on the pupil.

In-service training programme: This is offered to trainee counsellors to promote in them an understanding of the core facilitative conditions of counselling. It is a continuous process for counsellors, as with other professions, even after training and in the work environment. In-service training programmes for counsellors include the relevant courses and activities which counsellors participate in to upgrade their professional knowledge, skills and competences in the counselling profession. It encompasses all forms of education and training given to the counsellor who is already practicing the counselling profession either within or outside the school system (Osamwonyi, 2016). In-service training is very relevant in the counselling profession.

Remedial laboratory programme: This is a service that helps with students reading skills because reading is a crucial part in all subject areas. This programme is designed to help students improve their reading techniques and prepares them for their studies while in school and for their future careers. Students should be "encouraged to read more using games. When students associate reading with a fun game, they want to do it at all time" (UNICHECK, 2015, para. 3). "Many students struggle to understand the purpose of a paragraph or chapter in a book". It is important to help students increase their reading comprehension. This is a key to educational success or failure (Kelly, 2019, para. 6).

Career library service: This involves the provision of career information to help students with their career choice. It helps students in researching various careers whether they are interested in such careers or not. The career library provides information about various career to give students enough background on their choice of career. The advanced career library has a collection of computers to give students internet access to the best job-searching websites and career-related materials (Weber State University, 2019). A career library gives "detailed career information on hundreds of occupations including job description, training/education, employment projections, salary/pay and more" (Career Information-All careers, 2019, para. 1). Career Counsellors offer assistance to students who need information about their career of interest.

Career week/day programme: This is an avenue to introduce students to available jobs. Professionals from various fields are invited to discuss their occupations with students. The vast amount of career options in today's world has revealed the urgent need for assisting students to be exposed to and allowed to explore different career interests and possibilities. It is essential that students receive career counselling in school through the organization of career day/week so that they are better prepared for life after school and the transition into adulthood and the workforce (Hilling, 2017). The primary goal of career guidance and counselling is to make it 
possible for students to see and explore their unlimited endowed options (Amoah, Kwofie \& Kwofie, 2015). There are numerous benefits to having career-focused programmes in schools to prepare students for their future with the hope of making their choice easier. During career day/week, students have the opportunity to learn about exciting careers from people who work in those fields. This encourages children to start thinking about what they might want to be and what career they will choose in adulthood (Schreiner, 2018).

Excursion/Field trips: This is used in the vocational guidance of students. Excursion or field trip is synonymous with learning outside the classroom. It is an active process, where students encounter authentic problems, construct novel hypotheses, test for real solutions and interact with others to make sense of the world around them (Claiborne, Morrell, Bandy \& Bruff; Smith \& Fedesco, 2020). Field trips/excursions to a high extent help students to develop the ability of obligation and this significantly enhances their performance in their chosen area of study (Nnamonu, Anih, Nzewi, Ogbodo, Aleke, Kama \& Ndukwe-Ani, 2016).

\section{Benefits of guidance and counselling services in ODL programmes}

Every guidance and counselling service discussed is of immense benefit to students because each of these services address every aspect of the student's life. It is also important to consider the benefits to be gained when they partake in these services. Some of the benefits of these services to all students include, but are not limited to the following;

Orientation service helps students locate and use facilities easily. Appraisal service helps students understand themselves, their aptitudes, abilities, interest, strengths and weaknesses. It gives counsellors a better understanding of students and the circumstances surrounding their behaviours and attitudes. Information service exposes students to further educational, vocational and persona-social opportunities. Counsellors assist students to narrow down their choices out of several alternatives. Counselling service empowers students to resolve confusion in decision making with regards to their educational, vocational and personal social needs.

Planning service helps students plan effectively for their future. Research service exposes students to the application of new problem-solving techniques derived from intensive scientific investigation.

Placement service prevents students' frustration and job dissatisfaction in future as they are placed in the right schools and classes. Follow-up and Follow-along service reveal to students their progress during and after therapy, pointing to counsellors where and when modifications can be made. Referral service exposes students to other professionals they can consult for better professional help. Consultancy service equips students with knowledge and skills to help them 
meet their needs adequately. This might involve a third party, for example, a parent or a teacher. Evaluation service reveals the feelings of students about their experiences during therapy. It reveals to counsellors the extent to which all other services have been successfully implemented and the effectiveness of counselling methods used on students. Testing service reveals the problem areas of students, if there is any change or need for a counsellor's attention.

Motivational service encourages students to seek counselling voluntarily. The Cumulative record is of benefit to students as contact can be quickly made to family members in case of crisis. In-service training helps in updating the skills of teachers which they can apply to classroom teaching. Students are aware of new techniques and development, especially in a fastchanging technological world. Remedial laboratory service helps students improve their reading skills. This translates to effective lesson delivery as teachers have students who assimilate faster and better. Career library service provides career information to help students with their career choice. Counsellors are able to guide students on their choice based on their abilities, aptitudes and interest. Career Day/week gives students in depth knowledge of their choice of career. Counsellors are helped by invited professionals from various fields to discuss details of their occupation with students. Excursion/field trips help students gain on-the-job and original experiences in their choice of career.

\section{How ODL Students Can Access Guidance and Counselling Services.}

Guidance and counselling services is best provided in a one-on-one, face-to-face or person-toperson(s) contact. However, this may not be possible for ODL students because of environmental separation. ODL students can however access guidance and counselling services with consideration on their peculiarities.

\section{Orientation service}

Orientation service is organized to help new students locate and use facilities easily. It also saves time for lecturers as they do not have to always spend time describing or taking students to these facilities. This service is rendered by bringing all students together to inform them about the university, her vision and mission, faculties and department in the university, facilities in the university, principal officers and lots more in a week full of activities. However, ODL students may not have the opportunity to access this service because they are not readily available to physically attend an orientation programme. With the presence of information communication technologies ICTs and internet, the counselling unit in conjunction with the university could have a platform on the university's portal where information about the university in video form will be uploaded for all students to compulsorily familiarize with. In addition to this, a general study (GST) course could be developed to assess students' knowledge about the university in their first semester. 
Appraisal, Testing and placement services help students understand themselves, their aptitudes, abilities, interest, strengths and weaknesses. It gives counsellors a better understanding of students and the circumstances surrounding their behaviours and attitudes. Counsellors in the open and distance learning setting can appraise students by utilizing epsychological tests. The responses of the students in the e-psychological test would be analysed, the result and its interpretation would later be communicated to students. Decisions and placements are also initiated based on the result of the analyses.

\section{Information, Career Library and Career week/day programme services}

Academic or educational information, vocational or career information and personal-social information could be made available to ODL students to have unrestricted access electronically via students institutional e-mail addresses, counselling unit portal or on social media platforms. Videos of an interview with professionals in diverse fields should be uploaded for students on the designated career day or week.

Counselling, planning and research services: It is best for ODL students to meet the counsellor on a face-to-face contact to resolve challenges they might encounter in their daily experiences. Nevertheless, the distance learner could benefit from individual or group counselling sessions via video chat platforms like Skype, WhatsApp and Facebook video chat and lots more. During counselling sessions, the counsellor could guide students in mapping out plans and actions to make such plan a reality. The output from researches conducted by counsellor could also be applied to assist students during counselling sessions.

Excursion/Field trips: Physical presence during excursions most times is preferable for students who value first-hand information. When this is impossible, the information in video clips or picture formats of field trip scenes could be made available to students via the counselling unit's page on the school portal.

Follow-up and Follow-along service: The performance of a student during and after counselling, and after graduation can be monitored via the student's social media handle.

Referral service and Remedial laboratory programme: ODL students can access referral services when the counsellor transfers or recommends them to other professionals that will best manage their cases. Students could be referred via emails to other professionals. Tracking the student's progress report could also be done using emails and phone calls.

Evaluation service: Experience of students during counselling sessions could be evaluated using specially designed online forms. 
Cumulative record keeping: Cumulative records of students could also be archived in; CDROM, flash drives or cloud. Information on students could be retrieved whenever the need arises

\section{The Expected output of Professional Guidance and Counselling services for ODL Students}

Figure 1 was adapted from the proposed conceptual model of Ehren, Altricher, McNamara and O'Hara (2013: P. 14). The original model was on the intended effects of European Inspectorates of Education in six countries (Netherlands, England, Sweden, Ireland, Austria and the Czech Republic). The Inspectorates of Education in the six countries focused on "good education in individual schools and /or the education system as a whole", which succinctly describe the intended effects of education (Ehren et al., 2013: P. 14).

The model in this study like the original model, presents at a glance, the expected output of guidance and counselling services for ODL students. The aim is to draw attention to the fact that adequate implementation of these services will translate to improved school, workplace and family environment which will lead to a safe school, out of school and workplace environment for ODL students. The model reveals that adequate input and implementation of all guidance and counselling services will help in addressing the problems and challenges of students. These challenges faced by students in conventional universities include; academic, vocational and personal social needs such as; financial needs, peer pressure, substance addiction and abuse. Students in ODL programmes, in addition to the needs mentioned above, are faced with workplace/work pressure challenges, family/financial and social demands. The process involves the offering of guidance and counselling services by experts with complete cooperation from teachers/lecturers in these institutions who can also benefit from these services. Stakeholders can help this process through the provision of facilities and materials to enhance the adequate provision of counselling services, teaching and learning. The expected outputs are; good behaviour, improved academic performance and a safe and improved school, out of school, workplace and family environment. The purpose of this is to produce students who are well equipped and prepared for the changes and uncertainties of the world of work in particular and the society in general. 
Volume 2, 2020

\section{An adapted model for Guidance and counselling services in ODL Programmes}

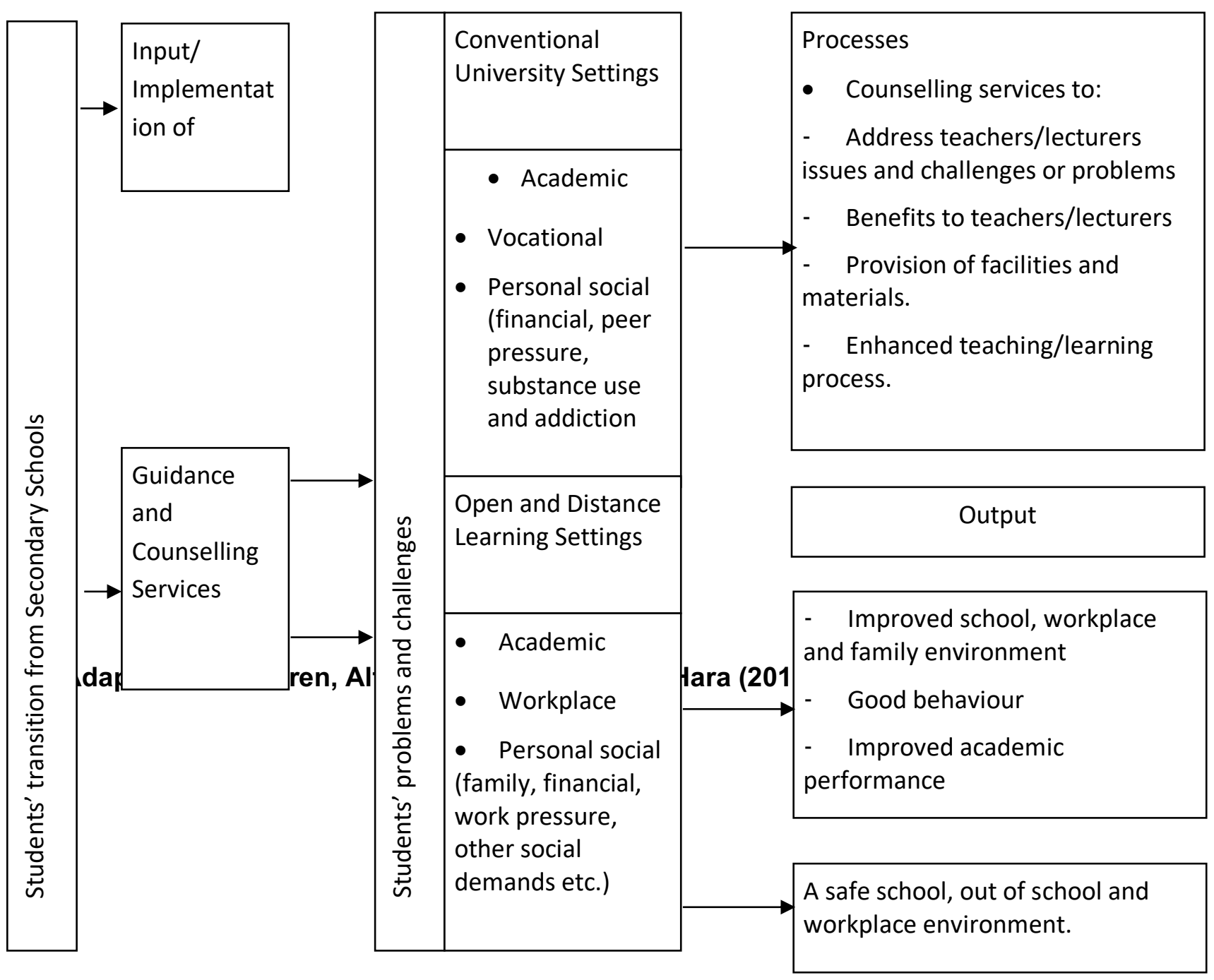




\section{Conclusion and Recommendations}

Effective provision of guidance and counselling services to students using diverse forms of ICT tools in ODL institutions will help them cope with the demands of studying from a distance and outside pressures resulting from family, workplace and environmental factors. Creating an effective learning environment through inclusion of all counselling services in the ODL institutions in Nigeria, will not only motivate ODL students to have increased motivation for learning, but it will also check attrition rates in ODL institutions and encourage students to have access to and utilize all counselling services in their institutions whenever challenges arise in their family or workplace to threaten the completion of their studies. No counselling service should be neglected in the ODL institutions because the students in addition to their studies, are faced with other demands and external factors.

The following recommendations are made by the authors:

Guidance and counselling services are designed to provide professional, systematic and psychological help to ODL students like the conventional students with the aim of encouraging their academic, vocational, social, emotional and personal adjustment or development. This can be accomplished through individuals/small group counselling sessions using various information communication technologies (ICTs) and social media platforms. Since distance education lacks the face-to-face contact that is present in the conventional education setting, necessary infrastructure, equipment and fund should be available to provide means of communication (which is an integral and most important component of distance education) to students especially because of the peculiarities of their situation as distance learners.

Stakeholders in the educational sector should ensure that all guidance and counselling services are rendered in all school settings (conventional and ODL). None of these services can be ignored or treated as more important than the other. No school setting should also be treated as more important than the other. Proper utilization of these services should also be ensured.

Counsellors should be ready and versatile to render guidance and counselling services to ODL students using diverse forms of information communication tools and social media platforms.

Awareness Programmes should be created through online seminars and workshops to educate ODL students on the benefits of guidance and counselling services and various ways to access them.

More counsellors should be employed in all ODL programmes to cope with the increasing demands of students, and to enhance better productivity and practice by students at the end of their programme. 


\section{REFERENCES}

Adeusi, S. O., Adekeye, O. A., \& Babalola, O. 2016. Influence of guidance and counselling on Students' motivation and school adjustment among Covenant University students, Ogun State. Covenant International Journal of Psychology. 1: 11-21.

Agi, C. 2016. Role of Students' Orientation as School Adjustment among Students of Tertiary Institutions. Available at https://www.researchgate.net/publication/315787241. Accessed 21 August 2020.

Ahimie, B., Ikuburuju-Orola, A., \& Lawal, K. (2018). Counsellors' reactions to the implementation of guidance and counselling services in Lagos State School System. Journal of Professional Counselling. 1: 73-79.

Amanchuku, R. N., \& Ololube, N. P. 2015. Excellent school records behaviour for effective management of educational systems. Human Resource Management Research. 5: 12-17.

Amoah, S. A., Kwofie, I., \& Kwofie, F. A. A. (2015). The school counsellor and students' career choice in high school: the assessor's perspective in a Ghanaian case. Journal of Education and Practice, 6: 57-65.

Apuke, O. D., \& lyendo, T. O. 2018. University Students' Usage of the internet resources for research and learning: forms of access and perceptions of utility. Available at https://doi.org/10.1016/j.heliyon.2018.e01052. Accessed 20 August, 2020.

Berven, N. L., Thomas, K. R., \& Chan, F. 2015. An introduction to counselling for rehabilitation and mental health professionals. In: Chan, F., Berven, N. L., \& Thomas, K. R. (eds.). Counselling Theories and Techniques for Rehabilitation and Mental Health Professionals. New York: Springer Publishing Company.

Board, J. 2016. Guidance and School counselling- a brief history of school guidance and counselling in the United States. Available at https:/leducation.state university.com>educationencyclopedia. Accessed 4 March 2020.

Career Information - All Careers 2019. All Career Profiles. Available at Collegegrad.com https://collegegrad.com/careers/all. Accessed 20 February 2020. 
Carlevatti, J. 2018. Why is Attending College Orientation Important? Available at https://admissions.usf.edu/blog/why-is-attending-college-orientation-important. Accessed 21 August 2020.

Claiborne, L., Morrell, J., Bandy, J., Bruff, D., Smith, G., \& Fedesco, H. 2020. Teaching Outside the Classroom. Available at https://cft.vanderbilt.edu/guides-sub-pages/teaching-outside-theclassroom/ Accessed 23 August 2020.

Danku, L. S., Soglo, N. Y., Dordor, F., \& Bokor, M. J. 2015. Performance Appraisal in the Ghana Education Service, the Case of Basic School Teachers in Ho Municipality. International Journal of Managerial Studies and Research 3: 117-133.

Darling-Hammond, L., Flook, L., Cook-Harvey, C., Barron, B., \& Osher, D. (2019). Implication for educational practice of the science of learning and development. Journal of Applied Developmental Science, $24: \quad 97 \quad-\quad 140 . \quad$ Available at https://doi.org/10.1080/10888691.2018.1537791. Accessed 24 August 2020.

Ehren, M.C.M., Altricher, H., McNamara, G., \& O'Hara, J. 2013. Impact of School Inspections on Improvement of Schools-describing assumptions on causal mechanisms in six European Countries. Educational Assessment Evaluation and Accountability, 25: $3-43$. Available at https://doi:10.1007/s11092-012-9156-4. Accessed 19 August 2020.

Hilling, E. 2017. The Importance of Career Counselling and Post-Secondary Readiness for High School Students. Counsellor Education Capstone, 37: 1- 29.

HYATTRACTIONS 2015. As a good counsellor, Explain Briefly on Six Main Principles of Appraisal Techniques Introduction. Available at https://hyattractions. wordpress.com/2015/09/21/as-agood-counsellor-explain-briefly-on-six-main-principles-of-appraisal-techniques-introduction/ Accessed 22 August 2020.

Jegede, O. 2016. Open and distance learning practices in Nigerian higher institutions of learning. A Keynote Address at the $3^{\text {rd }}$ University of Ibadan Annual Distance Learning Centre Distinguished Lecture and Stakeholders' Forum, Held at the International Conference Centre, University of Ibadan, Thursday, $14^{\text {th }}$ \& Friday, $15^{\text {th }}$ July, 2016. Available at https://www.olugbemiroh.jegede.com. Accessed 19 August, 2020.

Kelly, M. 2019. 10 Reading comprehension strategies all students need: why addressing reading comprehension is necessary. Available at https://www.thoughtoo .com>reading-co... Accessed 20 March 2020. 
Logsdon, A., \& Blackburn, S. 2020. Your child's cumulative record or file. Available at https://www.verywellfamily.com/cumulative-file-definition-2161832. Accessed 23 August 2020.

Manthey, T. J., Brooks, J., Chan, F., Hedenblad, L. E., \& Ditchman, N. (2015). Motivational Interview. In: Chan, F., Berven, N. L., \& Thomas, K. R. (eds.). Counselling Theories and Techniques for Rehabilitation and Mental Health Professionals. New York: Springer Publishing Company.

Makinde, B. O., \& Akanni O. O. 2015. Fundamental approach to test administration: for counsellors, teachers and psychologists. Lagos: University of Lagos Press and Bookshop Ltd. Marshall, R. (2017). Career Days: Helping children Learn what they want to be. Available at Herlifemagazine.com>mothers-perspective. Accessed 15 January 2020.

McGrath, S., Ramsarup, P., Zeelen, J., Wedekind, V., Allais, S., \& Lotz-Sisitka, H. 2019. Vocational education and training for African development: a literature review. Journal of Vocational Eduction \& Training. Available at https://doi.org/10.1080/13636820.2019.1679969. Accessed 23 August 2020.

McLeod, J., \& McLeod, J. 2015. Research on embedded counselling: An emerging topic of potential importance for the future of counselling psychology. Journal of counselling psychology. 28: $27-43$.

Musika, F. \& Bukaliya, R. 2015. The Effectiveness of Counselling on students' Learning Motivation in Open and Distance Education. International Journal of Research in Humanities and Social Studies. 2: 85-99.

Namale, M. K., \& Awabil, G. 2018. Evaluation of Guidance services in senior high schools in Gomoa West District in the Central Region of Ghana. Journal of Education and practice. 9: 2330.

National Policy on Education (NPE). 2014. Federal Republic of Nigeria. National Policy on Education (NPE) $6^{\text {th }}$ Edition. Lagos: Nigerian Educational Research and Development Council (NERDC) Publishers

Nnamonu, E. I., Anih, F. P., Nzewi, U., Ogbodo, G. U., Aleke, C. O., Kama, I. E., \& Nduwe-Ani P. A. 2016. The Influence of Field Trips on Students' Performance in Biology: Educational and Counselling Implications in Nigeria. Australian Journal of Basic and Applied Sciences, 10: 18 23

CONTACT: Ahimie, B. bahimie@yahoo.com 
Onyemenam, C. T. 2018. Appraisal of guidance and counselling services in higher institutions in Niger state. Available at http://articlesng.com/appraisal-guidance-counselling-services-higherinstitutions-niger... Accessed 3 May 2020.

Osamwonyi, E. F. 2016. In-service education of teachers: overview, problems and the way forward. Journal of Education and Practice, 7: 83 - 87

Pannoni, A., \& Moody, J. 2020. How high school counsellors can help students, parents. Available at https://www.usnews.com/education/blogs/high-school-notes/2015/02/02/3-ways-high-schoolcounsellors-can-help-students-parents. Accessed 24 August 2020.

Popoola, B. I., \& Oluwatosin, S. A. (2018). Assessment and Testing in Counselling Practice. Advances in Social Sciences Research Journal, 5: 266-275

Qayyum, A., \& Zawacki-Richter, O. 2019. Open and distance education in asia, africa and the middle east. National perspectives in a digital age. In Zawacki-Richter, O \& Qayyum, A. (eds). The State and Open and Distance Education. Springer Open. Available at https://doi.org/10.1007/978-981-13-5787-9. Accessed 20 August, 2020.

Samanyanga, I., \& Ncube, D. 2015. An evaluation of guidance and counselling services offered to students in gwanda urban and peri-urban secondary schools. Zimbabwe Journal of Educational Research. Available at https://www.ajol.info/index.php.zjer/article/view/113961. Accessed 25 August 2020.

Saykili, A. 2018. Distance education: definitions, generations, key concepts and future directions. International Journal of Contemporary Education Research, 5: 2 - 17.

Scholars Hub Africa 2019. 6 benefits of attending freshman campus orientation. Available at https://www.scholarshubafrica.com/43649/6-benefits-attending-freshmen-campus-orientation. Accessed 21 August 2020.

Schreiner, E. 2018. Elementary School Career Day Activities. Available at http://classroom.synonym>elemen.... Accessed 20 March 2020.

Sheikh, W. R. 2016. What is the role of information in our life? Available at https://specialties.bayt.com/en/specialties/q/273535/what-is-the-role-of-information-in-our-life/ Accessed 24 August 2020.

Short, F., \& Thomas, P. 2015. Core approaches in counselling and psychotherapy. London and New York: Routledge.

CONTACT: Ahimie, B. bahimie@yahoo.com

(C) $\$$ BY Th (O) This work is licensed under a Creative Commons Attribution 4.0 International License. 
Suleiman, Y., Olanrewaju, M. K., \& Suleiman, J. M. 2019. Improving guidance and counselling services for effective service delivery in Nigerian secondary schools: implications for stakeholders in education. Journal of Multicultural Studies in Guidance and Counselling, 3: $75-89$.

Traxler, J. 2018. Distance learning-predictions and possibilities. Journal of Education Sciences, 8: 1 - 13 .

UNICHECK. 2015. Ways to help students improve their reading skills. Available at https://unicheck.com>blog>ways-to-he... Accessed 14 February 2020.

University of Central Florida. 2020. Counselling and psychological services: making a referral. Available at https://caps.sdes.ucf.edu/resoruces/referrals/Accessed 23 August 2020 Accessed 21 August 2020.

Weber State University Career Services. 2019. Career Library: Need help researching careers. Available at https://www.weber.edu>careerservices Accessed 20 March 2020.

Zafar, M. 2019. Career Guidance in Career Planning among Secondary School Students. Asian Journal of Education and Social Studies, 5: $1-8$. 